\title{
Quantitative stress echocardiography in pediatric patients with type-1 diabetes mellitus
}

\author{
Kai O Hensel,,$\frac{\text { Affl }}{\text { Cor }}$ \\ Corresponding Affiliation: Aff1 \\ Franziska Grimmer, $\stackrel{\text { Aff1 }}{\text { }}$ \\ Markus Roskopf, $\underline{\text { Aff1 }}$ \\ Andreas Heusch,, Affl \\ Andreas Jenke, $\stackrel{\text { Aff1 }}{,}$ \\ Stefan Wirth, $\underline{\text { Aff1 }}$
}

ArticleInfo

\begin{tabular}{|l|l|l|l||}
\hline \hline ArticleID & $:$ & 48 \\
\hline \hline ArticleDOI & $:$ & $10.1186 / 2194-7791-2-\mathrm{S} 1-\mathrm{A} 8$ \\
\hline \hline ArticleCitationID & $:$ & A8 \\
\hline \hline ArticleSequenceNumber & $:$ & 8 \\
\hline \hline ArticleCategory & $:$ & Meeting abstract \\
\hline \hline ArticleFirstPage & $:$ & 1 \\
\hline \hline ArticleLastPage & $:$ & 2 \\
\hline \hline ArticleHistory & $:$ & $\begin{array}{l}\text { RegistrationDate } \\
\text { OnlineDate }\end{array}$ \\
\hline \hline ArticleCopyright & & $\begin{array}{l}\text { Hensel et al.2015 } \\
\text { This article is published under license to BioMed Central } \\
\text { Ltd. This is an Open Access article distributed under the } \\
\text { terms of the Creative Commons Attribution License } \\
\text { (http://creativecommons.org/licenses/by/4.0), which permits }\end{array}$ \\
\hline unrestricted use, distribution, and reproduction in any \\
medium, provided the original work is properly cited.
\end{tabular}

Aff1

Department of Pediatrics, HELIOS Medical Center Wuppertal, Faculty of Health, Witten/Herdecke University, Wuppertal, Germany

Abstracts of the 51st Workshop for Pediatric Research

51st Workshop for Pediatric Research

Göttingen, Germany

16-17 April 2015 
This supplement has not been sponsored.

Meeting abstracts

\section{Aims}

Type-1 diabetes mellitus (T1DM) is among the most common chronic diseases in children. Serious long-term complications include both ultra-morphologic and functional cardiac impairment. Whether these pathologic processes already take place in the early phase of T1DM yet has to be determined. Aim of this prospective, blinded, clinical study was to assess the effect of T1DM on left ventricular (LV) myocardial function in pediatric patients using quantitative stress echocardiography.

\section{Methods}

We included 40 patients with T1DM (aged $11.53 \pm 3.1$ years) and 44 sex-matched healthy controls $(11.43 \pm 2.9$ years; $\mathrm{p}=0.91)$. Conventional and quantitative echocardiography was performed both at rest and during physical exercise on a bicycle. Myocardial strain and strain rate were measured using speckle tracking echocardiography.

\section{Results}

Children with T1DM had increased myocardial contractility both at rest and at all levels of physical stress testing when compared to healthy volunteers. At rest, T1DM patients had significantly higher circumferential strain rate $\left(-2.05 \pm 0.35 \mathrm{~s}^{-1}\right)$ than healthy controls $\left(-1.86 \pm 0.25 \mathrm{~s}^{-1} ; \mathrm{p}=0.016\right)$. During exercise, diabetic children showed more negative values for longitudinal strain rate $\left(-2.59 \pm 0.47 \mathrm{~s}^{-1}\right)$ than healthy controls $\left(-2.32 \pm 0.41 \mathrm{~s}^{-1} ; \mathrm{p}=\right.$ 0.021). Furthermore, in T1DM patients, disease duration inversely correlated with myocardial strain rate and serum $\mathrm{HbAlc}$ levels correlated with strain both at rest and during stress testing.

\section{Conclusion}

Long-term impairment of cardiac function in diabetic cardiomyopathy may be preceded by a transient phase of increased myocardial contractility early in the course of T1DM. The extent of hyperglycemia in childhood correlates with the alteration of myocardial contractility. 